Western North American Naturalist 71(4), (C) 2011, pp. 481-489

\title{
EVALUATION OF RELEASE STRATEGIES FOR CAPTIVE-REARED JUNE SUCKER BASED ON POSTSTOCKING SURVIVAL
}

\author{
Eric J. Billman ${ }^{1}$, Josh E. Rasmussen ${ }^{2}$, and Jackie Watson ${ }^{3}$
}

\begin{abstract}
The recovery program for the endangered June sucker (Chasmistes liorus) relies on population augmentation to overcome recruitment deficits. Successful recruitment of artificially propagated individuals is affected by release timing, release size, and rearing techniques. We examined the effect of release timing and release size (total length [TL] and a relative condition factor $\left[\mathrm{W}_{\mathrm{r}}\right]$ ) on recruitment probability of hatchery-reared June sucker (Utah Division of Wildlife Resources Fisheries Experiment Station [FES]) and captive-reared June sucker (Red Butte Reservoir [RBR] refuge population) stocked across multiple years. Because source and year effects were confounded, we assessed the probability of recruitment individually for each major stocking event (i.e., source $\times$ year combination). Successful recruitment occurred if an individual was recaptured or detected at least once during annual spawning runs up Utah Lake tributaries. For stocking events from RBR, probability of recruitment was highest in individuals stocked during spring and early summer but decreased as summer progressed. No difference existed between spring and fall stocking events. June sucker from the FES stocked in October had lower overall probability of recruitment than those stocked in August. The relationships between recruitment probability and TL and $\mathrm{W}_{\mathrm{r}}$ for stocking events from RBR were hump shaped, with peaks at approximately $375 \mathrm{~mm}$ TL and 100\%, respectively. For FES individuals, a positive relationship existed between recruitment probability and TL for individuals stocked during August only; no relationship existed between the recruitment probability and $\mathrm{W}_{\mathrm{r}}$. Release timing and release size affected the recruitment success of captive-reared June sucker; therefore, recovery plans should incorporate these factors in augmentation efforts to maximize augmentation efficiency and success.
\end{abstract}

RESUMEN.-El programa de recuperación para la especie de pez en peligro de extinción conocida como June sucker (Chasmistes liorus) se basa en el aumento de la población para superar los déficits de reclutamiento. El reclutamiento exitoso de los individuos propagados artificialmente es afectado por el momento en que se liberan, el tamaño al momento de la liberación y las técnicas de crianza. Examinamos los efectos que tienen el momento y el tamaño (el largo total [TL] y un factor de condición relativo $\left[\mathrm{W}_{\mathrm{r}}\right]$ ) al tiempo de la liberación sobre la probabilidad de reclutamiento de Chasmistes liorus criados en piscifactoría (Utah Division of Wildlife Resources Fisheries Experiment Station [FES]) y en cautiverio (población protegida de la Red Butte Reservoir [RBR]) introducidos durante varios años. Debido a que se confundieron los efectos de la fuente y el año, evaluamos individualmente la probabilidad de reclutamiento de cada evento mayor de introducción (i.e., fuente $\times$ combinación de años). El reclutamiento exitoso ocurrió si se recapturaba o detectaba a un individuo al menos una vez durante los periodos en que desovaban a contracorriente en los ríos afluentes del Lago Utah. Para los eventos de introducción a partir de la RBR, la probabilidad de reclutamiento fue más elevada cuando los individuos se introdujeron durante la primavera y a principios de verano; sin embargo, disminuyó a medida que avanzaba el verano. No hubo diferencia entre las introducciones de primavera y otoño. Los Chasmistes liorus de la FES que fueron introducidos en octubre tuvieron en general menor probabilidad de reclutamiento que los que fueron sembrados en agosto. La relación entre la probabilidad de reclutamiento y el TL y el $W_{\mathrm{r}}$ para los eventos de introducción a partir de la RBR tenían una forma de campana con su pico más alto aproximadamente en $375 \mathrm{~mm}$ de TL y en 100\%, respectivamente. Para los individuos de la FES, hubo una relación positiva entre la probabilidad de reclutamiento y el TL de los individuos introducidos solamente en agosto; no hubo ninguna relación entre la probabilidad de reclutamiento y el $\mathrm{W}_{\mathrm{r}}$. El tamaño y el momento de liberación afectaron el éxito de reclutamiento de los Chasmistes liorus criados en cautiverio; por lo tanto, para maximizar el éxito y la eficiencia en el aumento de la población, los planes de recuperación deben incorporar estos factores a los esfuerzos por incrementarla.

Recovery programs for threatened and endangered fish species often rely on artificially propagated individuals to rapidly bolster depleted populations and to increase the probability of persistence both at the population and species level (George et al. 2009). Consistent recruitment of repatriated individuals into the adult (i.e., reproducing) population is the key measure of the success of augmentation and recovery programs (Le Vay et al. 2007). Artificial propagation, however, often results in reduced physiological performance and evolutionary fitness, as well as increased phenotypic variation and physical deformities among captive-reared

${ }^{1}$ Department of Biology, Brigham Young University, 401 WIDB, Provo, UT 84602 . E-mail: ericbillman@gmail.com
${ }^{2}$ U.S. Fish and Wildlife Service, Klamath Fish and Wildlife Office, 1936 California Avenue, Klamath Falls, OR 97601.

${ }^{3}$ Utah Division of Wildlife Resources, Central Region Office, 1115 N. Main Street, Springville, UT 84663. 
fish (Unwin 1997, Berejikian et al. 2001, Davis et al. 2004, Belk et al. 2008). Nevertheless, traditional hatchery methods can be modified to increase the physiological performance of artificially propagated individuals. Alternative methods of rearing captive individuals in a more natural setting (e.g., refuge populations or in situ cage culture) have been explored in attempts to minimize hatchery effects and to produce wild-adapted fish that will have a higher probability of recruitment (Fairchild and Howell 2004, Huntingford 2004, Billman and Belk 2009, Rasmussen et al. 2009). Factors including release size, release timing, release habitat, and stocking density can also contribute to the survival and recruitment of repatriated fish (Blankenship and Leber 1995, George et al. 2009). Augmentation and recovery programs should consider release factors and how they affect recruitment to ensure that efforts contribute to enhancement success.

A primary component of the recovery efforts for the endangered June sucker (Chasmistes liorus) is augmentation of the wild population with captive-reared fish (USFWS 1999, Andersen et al. 2007). The June sucker is a longlived (maximum age $>40$ years; Belk 1998), zooplanktivorous lake sucker endemic to Utah Lake, Utah, USA: a shallow, freshwater remnant of the ancient Lake Bonneville (Whitney and Belk 2000). The species was listed as federally endangered in 1986 due to low population numbers (estimated to be $<400$ spawning individuals) and loss of spawning and rearing habitat in tributaries to Utah Lake (USFWS 1999, Cooke et al. 2005). Habitat enhancement and restoration projects on the Provo River and other major tributaries are a major component of the recovery plan to achieve population persistence through natural production and recruitment. Until that goal is achieved, artificially propagated fish from hatchery production, growout ponds, and refuge populations will be released into Utah Lake to offset recruitment deficits and increase population size (Andersen et al. 2007).

Recruitment success of captive-reared June sucker has recently been shown to be affected by source of repatriated fish (hatchery vs. refuge) and release size (Rasmussen et al. 2009). However, success of stocking events has varied greatly among years, possibly due to differences in release timing among years. To evaluate and refine the augmentation and recovery plan for
June sucker, all release factors that can contribute to recruitment success should be examined (Blankenship and Leber 1995). In this study, we examined the effect of release timing and release size on recruitment success of hatchery-reared June sucker and captive-reared June sucker from a refuge population.

\section{Methods}

We analyzed the probability of stocked June sucker recruiting into the spawning population. Since augmentation began in 1994, captivereared June sucker have been stocked in Utah Lake from 3 sources: Utah Division of Wildlife Resources (UDWR) Fisheries Experiment Station (FES), Red Butte Reservoir (RBR), and Camp Creek Reservoir (Table 1). For further information regarding stocking events, site characteristics, and rearing techniques, see Rasmussen et al. (2009) and Andersen et al. (2007). For this study, we selected major stocking events (source $\times$ year combinations) that consisted of multiple stocking occasions within the year and that resulted in more than 50 fish being recaptured. Additionally, we only included major stocking events wherein the fish were marked with passive integrated transponder (PIT) tags prior to stocking; these tags allowed us to identify individual fish such that upon recapture we could determine stocking source and date for each fish. These criteria limited the major stocking events considered in this analysis to one event from the FES (1995) and 3 events from $\operatorname{RBR}(2001,2004$, and 2005; Table 1). June sucker from the FES 1995 event were stocked during the months of August $(n=1891)$ and October $(n=924)$. Stockings from RBR occurred in 2001 ( $k=2$ stocking events), 2004 ( $k=7$ stocking events), and 2005 ( $k=35$ stocking events). Stocking events from RBR in 2001 occurred in May $(n=471$ fish) and October $(n=221$ fish). In 2004, 1637 June sucker from RBR were stocked between 10 June and 21 July $2004(\bar{x}=234$ fish per stocking event). Similarly, 8124 June sucker from RBR were stocked between 26 April and 14 June 2005 $(\bar{x}=232$ fish per stocking event).

Recruitment of a stocked June sucker was determined successful if an individual was recaptured or detected at least once during the spawning run in a tributary to Utah Lake after the time of stocking $(1995,2001,2004$, and 2005) through the end of the 2009 spawning run. 
TABLE 1. Summary statistics since 1994 for major stocking events of June sucker from 3 locations into Utah Lake. Events are only included if fish were marked prior to release with a passive integrated transponder tag, rather than a coded wire tag. The number of recaptures reflects the total number of June sucker from each stocking event that have been recaptured at least once during spawning runs in Utah Lake's tributaries through the 2009 spawning run. Stocking events in bold were used in this study.

\begin{tabular}{|c|c|c|c|c|}
\hline Source & Year & Stocked & Recaptures & $\mathrm{TL}$ mean $\pm \mathrm{SD}(\mathrm{mm})$ \\
\hline Camp Creek Reservoir & $\begin{array}{l}2001 \\
2004 \\
2005\end{array}$ & $\begin{array}{r}904 \\
1060 \\
862\end{array}$ & $\begin{array}{r}52 \\
9 \\
7\end{array}$ & $\begin{array}{l}266.7 \pm 62.1 \\
168.0 \pm 53.6 \\
223.4 \pm 45.5\end{array}$ \\
\hline Fisheries Experiment Station & $\begin{array}{l}1994 \\
1995 \\
1996 \\
1999 \\
2004 \\
2005 \\
2006\end{array}$ & $\begin{array}{r}1527 \\
2873 \\
295 \\
692 \\
3606 \\
1029 \\
1557\end{array}$ & $\begin{array}{r}7 \\
67 \\
0 \\
3 \\
0 \\
4 \\
4\end{array}$ & $\begin{array}{l}202.8 \pm 39.3 \\
212.8 \pm 51.0 \\
261.3 \pm 42.0 \\
268.4 \pm 36.9 \\
162.4 \pm 42.0 \\
225.7 \pm 70.3 \\
294.2 \pm 67.7\end{array}$ \\
\hline Red Butte Reservoir & $\begin{array}{l}\mathbf{2 0 0 1} \\
\mathbf{2 0 0 4} \\
\mathbf{2 0 0 5} \\
2006\end{array}$ & $\begin{array}{r}700 \\
1638 \\
8375 \\
841\end{array}$ & $\begin{array}{r}266 \\
111 \\
749 \\
47\end{array}$ & $\begin{array}{l}357.5 \pm 40.1 \\
384.5 \pm 25.7 \\
281.0 \pm 77.6 \\
203.3 \pm 33.2\end{array}$ \\
\hline
\end{tabular}

Prior to 2007, the Provo River was surveyed annually by UDWR personnel using a weir, fyke nets, night spotlighting, or some combination of these techniques (Rasmussen et al. 2009). Beginning in 2007, PIT-tag antennas, in addition to other survey techniques, were used in the Provo River to record June sucker in the spawning run. Additionally, PIT-tag antennas were used in Spanish Fork River in 2008 and 2009 and in Hobble Creek and Battle Creek in 2009. We assume that fish that were recaptured or detected in any of these tributaries were searching for a spawning location.

To assess the patterns in recruitment after stocking, we used nonparametric smoothing methods (locally weighted scatterplot smoothing; LOESS) using the Design package (Harrell 2007) of the statistical software $\mathrm{R}$ (R Core Development Team 2008). We analyzed each major stocking event (source $\times$ year combination) separately, because the unbalanced design confounds the source and year effects that would be included in a single model. Additionally, stocking strategies (e.g., timing, size of fish, etc.) differed between years even for stocking events from the same source. Therefore, we were unable to use a single model for all stocking events and instead analyzed each major stocking event individually. For stocking events from RBR in 2004 and 2005, the probability of recruitment, or the probability of being captured at least once during the annual spawning run, was compared separately to 3 continuous variables: ordinal day of the year, total length (TL) at time of stocking, and a relative condition factor $\left(\mathrm{W}_{\mathrm{r}}\right)$. The relative condition factor is the ratio of the observed weight of an individual relative to the expected weight for the individual's length determined from lengthweight linear regression methods for each year individually (Pope and Kruse 2007, Ramussen et al 2009). Trends in the relationship between recruitment probability and each continuous variable were assessed for each year individually for the 2004 and 2005 stocking events from RBR.

The stockings from FES during 1995 and RBR during 2001 occurred in 2 relatively discrete events (i.e., across a short period) each and are therefore treated as 4 individual events identified by the month in which they occurred. For these 4 stocking events, the probability of being captured during the annual spawning run at least once was evaluated separately for each month across 2 continuous variables (TL and $\mathrm{W}_{\mathrm{r}}$ ).

LOESS for each variable for each stocking event was bootstrapped $(\mathrm{B}=1000)$, producing a distribution of values for each observed value, from which the $50 \%$ quantile at each value of the variable was taken as the mean. In a similar manner, values between which $95 \%$ of the bootstrapped values occurred (the 2.5\% and 97.5\% quantiles) were taken as the $95 \%$ confidence intervals.

\section{Results}

For stocking events from RBR in 2004 and 2005 , the probability of recruiting to the 


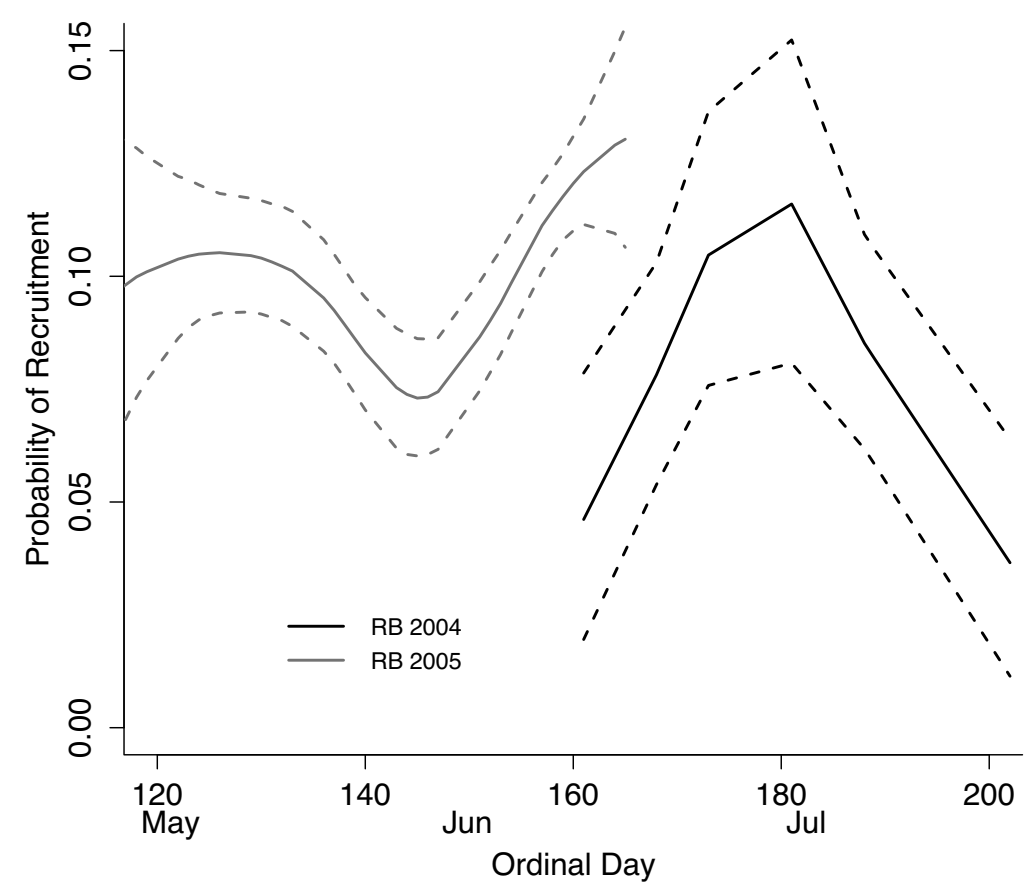

Fig. 1. Locally weighted scatterplot smooth of the relationship between probability of recruitment into the spawning population and day of the year (ordinal day) that stocking occurred for individuals stocked into Utah Lake from Red Butte Reservoir during 2004 and 2005. Confidence intervals $(95 \%)$ were obtained through bootstrapping $(\mathrm{B}=1000)$.

spawning population increased between late May (ordinal day 145) and the beginning of July (ordinal day 182; Fig. 1). For stocking events after the beginning of July, the probability of recruiting to the spawning population steadily declined. Individuals originating from the October 1995 FES stocking event generally exhibited lower recruitment probabilities compared to the August 1995 stocking event (Fig. 2). Probability of recruitment was higher for the May 2001 RBR stocking event compared to the October 2001 RBR stocking event; however, differences were not as pronounced as differences in the 1995 FES stocking events (Fig. 2).

Stocking events from RBR for all years exhibited a peak in the relationship between TL and recruitment probability at approximately $375 \mathrm{~mm}$ TL (Fig. 2). Confidence intervals at the margins of the distributions are fairly wide due to relatively small sample sizes at these lengths, with the exception of RBR 2005, which had a more even distribution of individuals across the range of lengths. For FES fish stocked in August 1995, a positive relationship existed between recruitment probability and TL (Fig. 2). No relationship between recruitment probability and TL was observed in the October 1995 stocking event from the FES.

Similar to TL, the $\mathrm{W}_{\mathrm{r}}$ of fish from RBR exhibited a humped relationship with the probability of recruitment (Fig. 3). Recruitment to the spawning population was most probable for individuals that had a calculated $\mathrm{W}_{\mathrm{r}}$ of approximately 100_ or in other words, had an observed weight that was nearly equal to the predicted weight for their TL from the regression analysis. Individuals that were lighter or heavier than predicted for their specific TL had lower probabilities of recruiting into the spawning population. In general, the probability of recruitment relative to $\mathrm{W}_{\mathrm{r}}$ of fish originating from the FES was uniform, with no distinct pattern between months in which stocking occurred (Fig. 3).

\section{DisCUSSION}

The success of augmentation programs geared toward bolstering endangered species is measured simply by recruitment of stocked individuals into spawning populations (Le Vay et al. 2007). However, recruitment is dependent on many factors related to the individual, to 
(A) Red Butte 2004

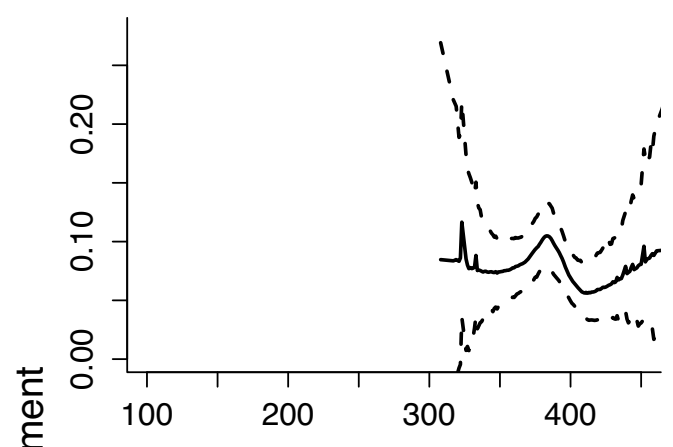

(C) FES 1995

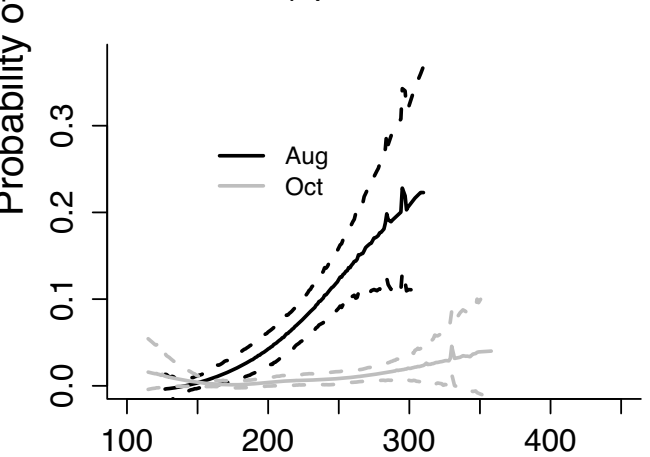

(B) Red Butte 2005

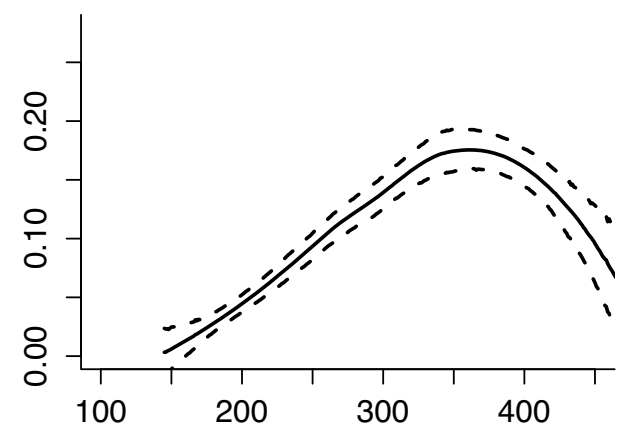

(D) Red Butte 2001

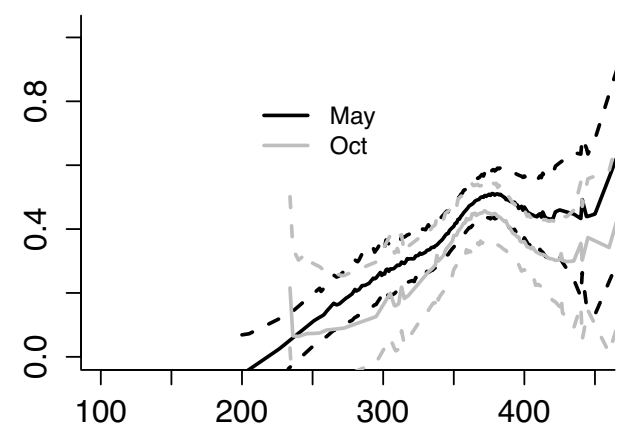

Total Length $(\mathrm{mm})$

Fig. 2. Locally weighted scatterplot smooth of the relationship between probability of recruitment into the spawning population and total length at the time of stocking for individuals stocked into Utah Lake for 4 separate groups from Red Butte Reservoir and the Utah Division of Wildlife Fisheries Experiment Station (FES). Confidence intervals (95\%) were obtained through bootstrapping $(\mathrm{B}=1000)$.

individual stocking events, or to the source population of individuals (Blankenship and Leber 1995). Efficient management of an augmentation program depends on an understanding of the patterns within and among these factors and the probability of recruiting, which can thereby guide stocking protocols and enable better management of source stocks.

The timing of a stocking event during the year was related to stocking success for each of the stocking events examined; however, this assessment of timing may simply be a surrogate for other effects, such as year, temperature, or acclimation period. For June sucker it appears that stocking in late spring or early summer is better than stocking in midsummer. Temperature and associated water chemistry differences between these periods are likely important factors, with higher temperature in midsummer compounding the stress on individuals due to handling, transportation, etc. (Piper et al. 1983, Kindschi et al. 2008). Additionally, the stress associated with high summer temperatures can cause abnormal behavior (e.g., swimming haphazardly at the water surface for a short period followed by a lethargic period at the water surface) that would further increase the stocked suckers' vulnerability to both aquatic and avian predators (Josh Rasmussen personal observation; Smith and Hubert 2003).

The comparisons of fall (October; FES and RBR) stocking with late summer (August; FES) and spring (May; RBR) stocking had differing results. Stocking success for fish from the 
(A) Red Butte 2004

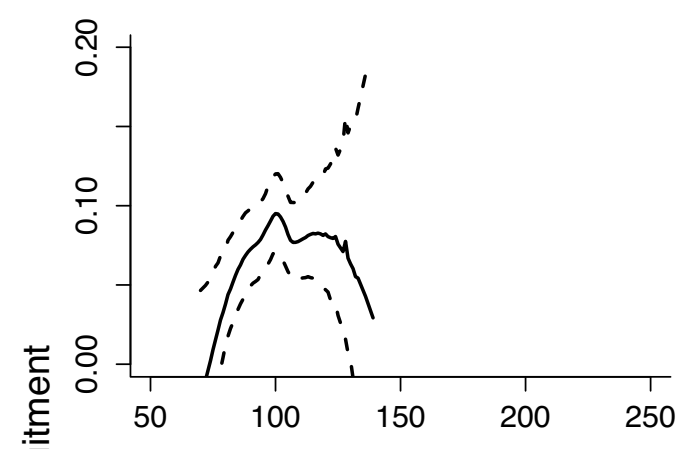

(C) FES 1995

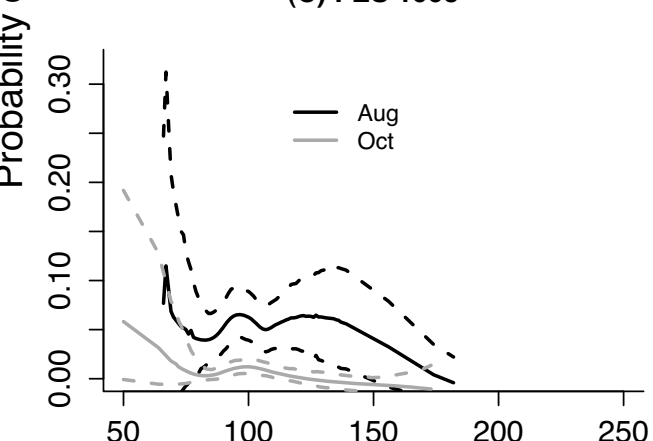

(B) Red Butte 2005

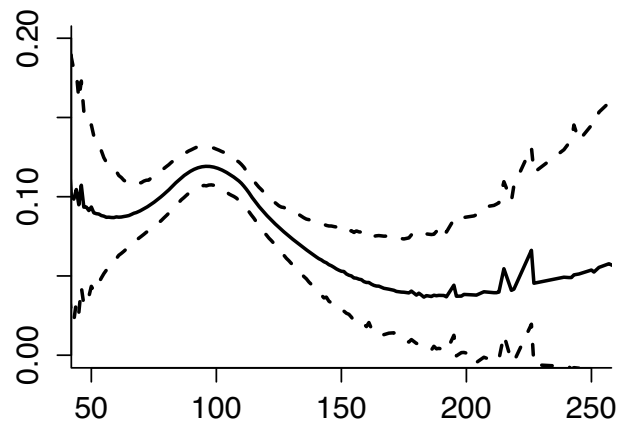

(D) Red Butte 2001

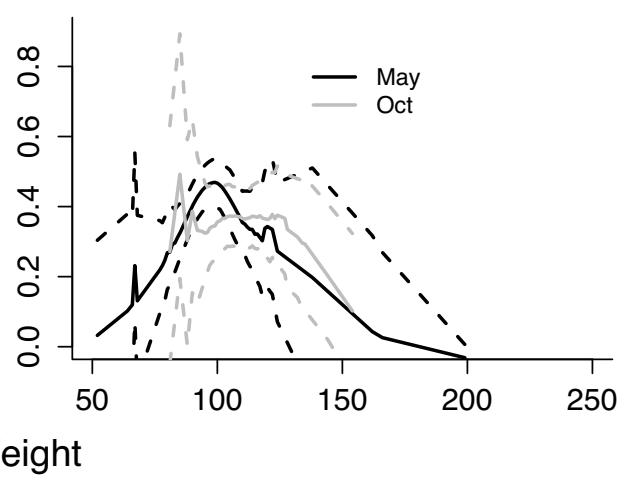

Fig. 3. Locally weighted scatterplot smooth of the relationship between probability of recruitment into the spawning population and a relative condition factor $\left(\mathrm{W}_{\mathrm{r}}\right)$ at the time of stocking for individuals stocked into Utah Lake for 4 separate groups from Red Butte Reservoir and the Utah Division of Wildlife Fisheries Experiment Station $(\mathrm{FES})$. $\mathrm{W}_{\mathrm{r}}$ compares observed weights to predicted weights at specific lengths generated from regression analysis such that $\mathrm{W}_{\mathrm{r}}=100$ indicates that observed weight equals predicted weight. Confidence intervals $(95 \%)$ were obtained through bootstrapping $(\mathrm{B}=1000)$.

FES was much higher for late summer (August) events compared to fall (October) events, although these estimates are based on relatively few recaptures (67 recaptures from a combined total of 2873 fish). While differences in stocking success may be due to differences in techniques between the 2 events, it is possible that for the October event, the short acclimation period before the stress of overwintering produced higher mortality. Individuals from the FES stocked in October had low survival regardless of size, unlike those stocked in August that demonstrated a positive relationship between probability of recruitment and total length. This pattern, or lack thereof, demonstrates a uniform factor (e.g., short acclimation prior to onset of winter and/or differences in stocking techniques or in abiotic factors between hatchery and lake environments) affecting all fish.

Conversely, differences in the probability of recruitment of individuals from RBR were minimal between the spring and fall events during 2001. While June sucker from RBR would still need to acclimate to the new environment, they were already acclimated to a natural environment (i.e., conditioned to natural prey; able to recognize, react to, and avoid predators) (Fairchild and Howell 2004, Huntingford 2004). Therefore, these fish would have required less time to acclimate than suckers from a benign hatchery environment. However, this explanation fails to explain why fish from Camp Creek Reservoir have such poor success when stocked into Utah Lake (Table 1). 
Additionally, it is not possible to exclude year effects when comparing results between FES 1995 and RBR 2001 stocking events, as source and year effects are confounded.

Total length has an apparently strong effect on the probability of stocked individuals recruiting into the spawning population, but for a variety of reasons. For RBR, the best length for stocked individuals (approximately $375 \mathrm{~mm}$ $\mathrm{TL}$ ) is also around the size that individuals become reproductively mature in RBR (Billman and Crowl 2007). Smaller individuals are more likely to be strongly impacted by predation from walleye (Sander vitreus), white bass (Morone chrysops), and a variety of avian predators (Rasmussen personal observation; Belk et al. 2001). The decline in recruitment probabilities for RBR individuals larger than $375 \mathrm{~mm}$ TL may be the result of these mature individuals becoming adapted to lake spawning in RBR and therefore not responding to cues provided by tributaries in Utah Lake (Billman 2008). If this is the case, overall survival of this size class may be underestimated if RBR individuals stocked at large sizes survive in the lake but are never recaptured in tributaries. However, we would expect more of these large RBR individuals to be captured in lake-wide surveys. Alternatively, large fish may not transport as well as smaller fish and therefore may have a higher probability of mortality immediately after being stocked. For June sucker originating from the FES, larger individuals had a higher probability of recruitment compared to smaller counterparts, but only for the August stocking event. Naïve hatchery fish would be particularly vulnerable to predation in Utah Lake, and this would potentially magnify the size effect on recruitment probability (Fairchild and Howell 2004, Huntingford 2004). Unfortunately, we cannot compare the FES with RBR to see if there is a similar effect of reaching reproductive maturity in a refuge or artificial habitat, because no FES fish were stocked at or after reaching reproductive maturity.

The condition $\left(\mathrm{W}_{\mathrm{r}}\right)$ of June sucker at the time of release affected probability of recruitment. A low $\mathrm{W}_{\mathrm{r}}$ indicates that an individual is likely in poor health, has been stressed, or is simply weak. We expect these individuals to have reduced survival relative to higher-condition individuals due to the stress of being captured, transported, and introduced into a new environment, as was demonstrated in RBR fish.
Interestingly, individuals from RBR with higher than expected weights for their length also had reduced survival relative to average individuals. This pattern was not observed in fish released from the FES. Individuals from RBR with a higher $\mathrm{W}_{\mathrm{r}}$ may be well adapted to a refuge environment (i.e., have some condition or behavior that allows them to excel in RBR), but the same benefit may not transfer to Utah Lake.

These analyses provide useful targets in determining stocking protocol and management practices. According to the findings of this study, stocking events from RBR, or refuge stocking in general, should occur during early summer or fall and avoid midsummer. Early summer may have more benefits because the timing allows stocked fish to be "imprinted" on tributaries and provides a longer period for them to adapt to new conditions before the onset of winter, thus increasing probability of overwinter survival. Optimal management of RBR includes development of a production model for the reservoir with a slot of lengths targeted for stocking (i.e., individuals selected for transport to Utah Lake that are not too small or too big; Buelow et al. 2006). This approach will produce efficient stocking and promote high production in the reservoir, given that at least some portion of larger individuals will remain (Billman 2005). Similar timing for FES stocking events should occur, with the exception that, given the novelty of the Utah Lake environment to these individuals, late summer should be utilized rather than fall because fall stockings appear to produce limited results.

While these suggestions can direct future augmentation efforts, there is still a need for further research regarding the most successful augmentation plan that will ultimately increase the June sucker population in Utah Lake. In particular, further research should examine the cause of yearly variation in successful recruitment. For each source of June sucker, there is evidence of year effects (Table 1), particularly for the FES (only 1 of 7 years resulted in more than 7 recaptures) and Camp Creek Reservoir (1 of 3 years resulting in more than 9 recaptures). June sucker originating from RBR have had the greatest success at recruiting into the reproducing population in Utah Lake even during years when fish from the FES and Camp Creek Reservoir had poor success (Table 1; Rasmussen et al. 2009). Therefore, further research could examine why fish from RBR have 
greater recruitment success than June sucker from the FES or Camp Creek Reservoir. Additionally, the FES hatchery facilities have recently been upgraded to provide better rearing conditions for June sucker (Andersen et al. 2007). In the coming years, it will be possible to determine the recruitment success of fish reared in the new facility and to assess the success of the new facility in augmenting the June sucker population in Utah Lake. Furthermore, better design and coordination of stocking events will minimize confounding and provide better statistical rigor to clarify these patterns and better direct management actions.

As demonstrated in this study, and consistent with research on this and other species (Unwin 1997, Billman and Belk 2009, Rasmussen et al. 2009, Taylor et al. 2009), survival and/or recruitment of stocked June sucker are affected by factors based on an individual's characteristics, on individual stocking events (e.g., release timing), and on source population. These effects lead to a high degree of variability in recruitment of stocked individuals, as demonstrated by the range in recruitment of June suckers from various stocking events, even within source populations (range of recruited individuals 0-749 for all stocking events; Table 1). Therefore, the augmentation program for June sucker demonstrates that a conservation rearing program should initially include a variety of methods (e.g., intensive rearing and seminatural refuge and grow-out sites), as well as exploration of optimal release sizes and release timing to maximize augmentation efficiency and success. Such a program would be better able to adapt stocking strategies according to successes and failures and thus develop the optimal augmentation plan to ensure that effort is not wasted and the goals of the augmentation program are achieved.

\section{ACKNOWLEDGMENTS}

We are grateful to Mike Mills for the invitation to present at the Lake Sucker Symposium at the Western Division of the American Fisheries Society 2010 Annual Meeting. River-return data from Battle Creek 2009 was graciously provided by Todd Crowl, Kevin Landum, and Brian Hines at Utah State University.

\section{Literature Cited}

Andersen, M.E., C.J. Keleher, J.E. Rasmussen, E.S. HaNsen, P.D. Thompson, D.W. Speas, M.D. Routledge,
AND T.N. Hedrick. 2007. Status of June sucker in Utah Lake and refuges. Pages 39-58 in M.J. Brouder and J.A. Scheurer, editors, Status, distribution, and conservation of native freshwater fishes of western North America: a symposium proceedings. Symposium 53, American Fisheries Society, Bethesda, MD.

BELK, M.C. 1998. Age and growth of June sucker (Chasmistes liorus) from otoliths. Great Basin Naturalist 58:390-392.

Belk, M.C., L.J. Benson, J. Rasmussen, and S.L. Peck. 2008. Hatchery-induced morphological variation in an endangered fish: a challenge for hatchery-based recovery efforts. Canadian Journal of Fisheries and Aquatic Sciences 65:401-408.

Belk, M.C., M.J. Whitney, and G.B. Schahle. 2001. Complex effects of predators: determining vulnerability of the endangered June sucker to an introduced predator. Animal Conservation 4:251-256.

Berejikian, B.A., E.P. Tezak, S. Riley, and A. LaRae. 2001. Social behavior and competitive ability of juvenile steelhead (Onchorhynchus mykiss) reared in enriched and conventional hatchery tanks and a stream environment. Journal of Fish Biology 59:1600-1613.

Billman, E.J. 2005. Population dynamics and foraging ecology of a June sucker (Chasmistes liorus) refuge population. Master's thesis, Utah State University, Logan, UT.

2008. Reproduction by June sucker in a refuge population: successful spawning in a lake habitat. Western North American Naturalist 68:475-482.

BiLLMAN, E.J., AND M.C. BELK. 2009. Growth and survival of juvenile June suckers in enclosures in Utah Lake: feasibility of modified cage culture for an endangered species. North American Journal of Aquaculture 71:281-286.

Billman, E.J., AND T.A. Crowl. 2007. Population dynamics of a June sucker refuge population. Transactions of the American Fisheries Society 136:959-965.

BLANKENSHip, H.L., AND K.M. LebER. 1995. A responsible approach to marine stock enhancement. American Fisheries Society Symposium 15:167-175.

Buelow, K., E.J. Billman, P. Cowely, M. Crawford, T.A. Crowl, C. Keleher, M. Slater, and K. Wilson. 2006. Red Butte Reservoir management plan. Draft from the Utah Department of Natural Resources, Utah Division of Wildlife Resources; U.S. Department of the Interior, U.S. Fish and Wildlife Service; Utah State University; Central Utah Water Conservancy District; USDA Forest Service; and Bureau of Reclamation to the June Sucker Recovery Implementation Program, Salt Lake City, UT.

Cooke, S.J., C.M. Bunt, S.J. Hamilton, C.A. Jennings, M.P. Pearson, M.S. Cooperman, and D.F. Markle. 2005. Threats, conservation strategies, and prognosis for suckers (Catostomidae) in North America: insights from regional case studies of a diverse family of nongame fishes. Biological Conservation 121:317-331.

Davis, J.L.D., A.C. Young-Williams, R. Aguilar, B.L. CarsWELL, M.R. GoOdison, A.H. Hines, AND M.A. KRAMER. 2004. Differences between hatchery-raised and wild blue crabs: implications for stock enhancement potential. Transactions of the American Fisheries Society 133:1-14.

Fairchild, E.A., AND W.H. HoweLL. 2004. Factors affecting the post-release survival of cultured juvenile Pseudopleuronectes americanus. Journal of Fish Biology 65:69-87. 
George, A.L., B.R. Kuhajda, J.D. Williams, M.A. CantRELL, P.L. Rakes, AND J.R. Shute. 2009. Guidelines for propagation and translocation for freshwater fish conservation. Fisheries 34:529-545.

Harrell, FE., JR. 2007. Design: design package, R version 2.1-1 [software]. Available from: http://biostat.mc .vanderbilt.edu/twiki/bin/view/Main/Design

HunTINGFORD, F.A. 2004. Implications of domestication and rearing conditions for the behaviour of cultivated fishes. Journal of Fish Biology 65:122-142.

Kindschi, G.A., M. Toner, W.C. Fraser, M.D. Routledge, M. Wilson, AND Y. Converse. 2008. Evaluation of thermal requirements for the propagation and recovery of June suckers. North American Journal of Aquaculture 70:1-7.

Le Vay, L., G.R. Carvalho, E.T. Quinitio, J.H. Lebata, V.N. UT, AND H. Fushimi. 2007. Quality of hatcheryreared juveniles for marine fisheries stock enhancement. Aquaculture 268:169-180.

Piper, R.G., I.B. McElwain, L.E. Orme, J.P. McCraren, L.G. Fowler, AND J.R. LEONARD. 1983. Fish hatchery management. U.S. Fish and Wildlife Service, Washington, DC.

Pope, K.L., and C.G. Kruse. 2007. Condition. Pages 423-427 in C.S. Guy and M.L. Brown, editors, Analysis and interpretation of freshwater fisheries data. American Fisheries Society, Bethesda, MD.
Rasmussen, J.E., M.C. BelK, And S.L. Peck. 2009. Endangered species augmentation: a case study of alternative rearing methods. Endangered Species Research $8: 225-232$.

R Development Core Team. 2008. R: a language and environment for statistical computing. Vienna, Austria. Smith, M.A., AND W.A. HubERT. 2003. Simulated thermal tempering versus sudden temperature change and short-term survival of fingerling rainbow trout. North American Journal of Aquaculture 65:67-69.

Taylor, M.D., D.S. Fielder, and I.M. Suthers. 2009 Growth and viability of hatchery-reared Argyrosomus japonicus released into open and semi-closed systems. Fisheries Management and Ecology 16:478-483.

[USFWS] United States Fish and Wildlife Service. 1999. June sucker (Chasmistes liorus) recovery plan. U.S. Fish and Wildlife Service, Denver, CO.

UnwIN, M.J. 1997. Fry-to-adult survival of natural and hatchery-produced chinook salmon (Oncorhynchus tshawytscha) from a common origin. Canadian Journal of Fisheries and Aquatic Sciences 54:1246-1254.

Whitney, M., AND M.C. BELK. 2000. Threatened fishes of the world: Chasmistes liorus Jordan, 1878 (Catostomidae). Environmental Biology Fishes 57:362

Received 17 September 2010 Accepted 9 August 2011 